\title{
SMART SERVICES AND THEIR BENEFITS FOR MANUFACTURERS FROM A GLOBAL PERSPECTIVE
}

\author{
Lucie Kanovska ${ }^{1, \mathrm{a}, *}$ \\ ${ }^{1}$ Brno University of Technology, Faculty of Business and Management, Kolejní 2906/4, Brno 612 00, \\ Czech Republic \\ akanovska@fbm.vutbr.cz \\ *Corresponding author
}

Cite as: Kanovska, L. (2018). Smart services and their benefits for manufacturers from a global perspective. Ekonomicko-manazerske spektrum, 12(2), 46-56.

Available at: dx.doi.org/10.26552/ems.2018.2.46-56

\begin{abstract}
Current manufacturers do not provide only tangible products to their customers, but also deliver services and integrated solutions in today's globalized environment. Furthermore, they effort also on implementing 'smart services'. Smart services allow by connected productservice systems to exchange data between their customers and the service providers. Smart services offer many benefits for both manufacturing companies as service providers and as well as for their customers. The aim of this paper is to investigate which benefits of smart services are the most significant for manufacturing companies. To address the research objective, a qualitative multi-case study was conducted among seven Czech electrotechnical SMEs, which have already started with smart service provision. The respondents operate in the same industry, but they provide a wide range of products and services to their customers with varying degrees of smart service orientation. The empirical part of the paper involves in-depth interviews with owners or with experienced senior managers in each case organization. The interviews were done from April 2017 to January 2018. The findings show the most important benefits for small and medium manufacturers and their customers.
\end{abstract}

Keywords: smart services; manufacturing companies; smart servitization; global area; Czech Republic.

JEL Classification: L8

\section{Introduction}

Globalization is accompanied by changes in technology, the liberalization of goods and services and greater mobility. It is about being present on the global market and develop new competitive strategies, where a strategic basis for understanding is crucial. Therefore, many manufacturers transform from industrial goods toward the provision of services. Moreover, they also add smart services to their service offerings. Smart service solutions in manufacturing companies include both hardware solutions as well as an essential service component in the current global area. Smart services can be seen as one of the enablers of servitization (Grubic \& Peppard, 2016; Neu \& Brown, 2008; Oliva \& Kallenberg, 2003).

Servitization is transformational process of shifting from a product-centric business model and logic to a service-centric approach (Kowalkowski et al., 2017). Smart services offer many benefits for both manufacturing companies as service providers and as well as for their customers. Moreover, smart services in manufacturing companies can improve value creation and profitability for both the business and customers. Manufacturers can collect data useful for innovation, research 
and development, positioning themselves as leaders in their industries. Benefits of smart services have been studied in some researches, but not so many studies have focused on SMEs and on one particular industry.

To fill the gap, the study presented in this paper explores current situation in the Czech electrotechnical SMEs and their attitudes to benefits from smart service provision. A qualitative multi-case study was conducted among seven Czech electrotechnical SMEs, which have already started with smart service development. The aim of the paper is to investigate which benefits of smart services are the most important for SMEs. According to the findings in the paper, the main benefits of smart service provision for manufacturers and their customers are from four main fields: differentiation from competition, product maintenance / repairs, reliability and safety of products, reducing costs.

\section{Service offering in manufacturing companies}

The manufacturing companies focus more on service-led growth to secure their position and to expand to competitive markets (Ostrom et al., 2015). Moreover, services become the center of the total offering, with products as add-ons to the services (Gebauer et al., 2011). The use of service differentiation in manufacturing takes advantage of the strategic, financial and marketing opportunities. Services lead to the creation of value based on the competency of the company and the customer (Vargo \& Lusch, 2008). Financial opportunities include additional service revenues throughout the product lifecycle (Wise \& Baumgartner, 2000). Marketing opportunities involve using services to augment the product offering and increasing the quality of the customer interaction (Mathieu, 2001). Similarly, Davies et al. (2007) indicates that services provide a more constant income, higher profit margins and require less asset allocation than manufacturing.

Vandermerwe \& Rada (1988) mentioned the term 'servitization' firstly. Servitization transform manufacturers to solution providers by adding value to their core products through services (Baines et al., 2017; Wise \& Baumgartner, 1999). Services and integrated solution can help to gain new sources of competitive advantage and value generation (e. g. Brax \& Jonsson, 2009; Oliva \& Kallenberg, 2003). Servitization is the process where companies generate greater value by increasing the services they offer to their customers (Vandermerwe \& Rada, 1988). The addition of services in product companies, at a theoretical level, looks like an essential element in increasing the value of a products' technical performance and securing a competitive position in a supply chain (Matthyssens \& Vandenbempt, 2008; Vandermerwe \& Rada, 1988).

Moreover, servitization improves the innovative capabilities in companies and create value at the consumer level by offering a balance of products and services (Visnjic \& Van Looy, 2013). Though, some latest empirical studies show that the addition of services do not guarantee the increase of firm performance (Benedetti et al., 2015; Kowalkowski et al., 2015). Product lifecycle and the threat of entry of new competitors are factors that affect the capacity to capture value from service implementation (Cusumano et al., 2015). Moreover, adding services to product companies needs a period of organizational transformation and if the producer is under stable market conditions the process of value capture can be never changed (Lepak et al., 2007).

\section{Smart services in manufacturing}

Allmendinger \& Lombreglia (2005) mentioned that "Soon, it will not be enough for a company to offer services; it will have to provide 'smart services'." Klein (2017) describes smart services as: "Smart services are technologically-mediated services actively delivered by the provider through accessing a remote asset and exchanging data through built-in control 
and/or feedback devices". Beverungen et al. (2017) describe smart service as the application of specialized competences, through deeds, processes, and performances that are enabled by smart products.

In the literature, the concept of smart services could be named also differently, such as: diagnostics and prognostics, new digital technologies, remote diagnostics, remote monitoring technology or teleservices (Grubic, 2014). Examples of remote monitoring technology supporting servitized strategy are in many various industries, e.g. aerospace, machine tools, computers and telecommunication networks, transport and telecommunication networks, medical, industrial equipment, marine, industrial equipment, oil and gas and energy (Grubic, 2014).

Digital technology, which are important for smart services, changes the way how product companies can compete and offer services (Porter \& Heppelmann, 2014; Vendrell-Herrero \& Wilson, 2016). "Digital Servitization" as substream of research, which was recently described (Vendrell-Herrero \& Wilson, 2016), is defined as the providing of IT-enabled (i.e. digital) services, which rely on digital components embedded in physical products (Schroeder \& Kotlarsky, 2015).

Digital servitization differs from servitization in three aspects: a) the marginal cost of digital services is near zero (Rifkin, 2014), b) whilst services are usually complementary to a product offering (Cusumano et al., 2015), digital services are often substitutes for traditional products (Greenstein, 2010), c) digital technologies, as with other disruptive technology, open new business opportunities that can be executed by new entrants (Christensen, 1997), especially hardware and software developers or retailers.

\section{Benefits of smart services}

Smart services provide a huge range of benefits for manufacturing companies as service providers and also for their customers in the global context. Küssel et al. (2000) state that smart services are more competitive, offer new sources of revenue, higher margins, and considerable cost savings. Regarding to monetary benefits, smart services provide also a variety of nonmonetary benefits. Some non-monetary benefits are seen in the opportunity to learn more from customers and their product using, establishing a basis for research and development, sales or marketing activities (Laine et al., 2010). Consequently, Wünderlich et al. (2015) emphasize smart services are gaining a considerable strategic importance in B2B and B2C contexts. Porter and Heppelmann (2014) summarize the importance of smart services: "[They] offer exponentially expanding opportunities for new functionality, far greater reliability, much higher product utilization, and capabilities that cut across and transcend traditional product boundaries".

Benchmarks present that companies offering smart services, get more than $50 \%$ of revenue and $60 \%$ of margins from services than from product sales (Allmendinger \& Lombreglia, 2005). Smart services and their possibility to remotely fix the products are very beneficial especially for small companies. They enable to decrease the costs and effort of their technician (Kamp et al., 2017). In the global context, by using smart services companies could save a lot of money, because they could repair many products remotely and thus eliminate travel and labor costs and time of their employees. Moreover, they can easily share information about products with customers and others, such as partners, suppliers across the whole world.

Customers can gain many benefits from smart services, such as "the value of removing unpleasant surprises from their lives" (Allmendinger \& Lombreglia, 2005). The benefits could be realized in the form of reduction of machine downtimes, optimized scheduling of maintenance, more safety, improved information flow and transparency as well as a reduction 
of labor costs and creation of a better work environment (Lee et al., 2014). According to literature reviewed, remote monitoring technology benefits the customer mainly through minimization of downtime and transfer of risks to the manufacturer (Grubic, 2014). Table 1 summarizes the findings about the benefits of remote monitoring technology for customers and manufacturers (Grubic, 2014).

Table 1: Benefits of remote monitoring technology

\begin{tabular}{ll}
\hline Paper & Benefits for the customer (C) and/or manufacturer (M). \\
\hline 1. Kiissel et al. (2000) & $\begin{array}{l}\text { Saves time in the error diagnosis and repair (C). } \\
\text { Removing unpleasant surprises (C), makes performance of products and } \\
\text { behaviors of customers visible (M). }\end{array}$ \\
Enables comparison between different machines and settings which helps in \\
3.Jonsson and Holmstrom(2005) \\
making better and more reliable predictions of the remaining useful life, \\
informs improvement and/or new product development initiatives (M). \\
Minimization of operational hold-ups (C), getting direct access to operational \\
data which reduces likelihood of receiving potentially erroneous and/or \\
misleading incident descriptions from the customer (M).
\end{tabular}

Source: Grubic (2014)

\section{Methodology}

Theoretical understanding of smart services is still almost at the beginning. Afterward, Grubic \& Peppard (2016) conclude that there is a lack of understanding how smart services are used by manufacturing companies. Wünderlich et al. (2015) state that "Despite the accelerating development of these smart services, academic research is still in its infancy. We see the need to further explore the effect that smart service has on organizations, customers and the evolving service landscape". Also Grubic \& Jennions (2017) mention that the research in this field is predominately technology oriented and lacking the wider assessment of the technology's value creation potential in a business context.

To know more about smart services in manufacturing, a qualitative research was conducted as a multi-case study among seven SMEs electrotechnical companies, South Moravian Region. The research investigated how smart services are provided by current manufacturing SMEs. The in-depth interviews explored following aspects: type of smart products and smart services, the length and way of smart service provision, customer perception of smart services, the reasons for starting with smart service provision, the benefits gained from smart services, barriers connected to smart service provision, gathering and using the data gained from smart services, specifics of Czech industrial market, collaboration with other firms and "learnings" for other firms which want to start with smart services. The part of the study focusing benefits gained from smart services was used for this paper.

All the case companies in the qualitative research were SMEs from the same industry electrotechnical producers and were selected based on purposive sampling. They operate in one industry, but they provide a wide range of products and services to their customers with varying 
degrees of service orientation. All case companies have been implementing smart services to their companies in different level and range.

Case companies mostly provided the following smart services: remote monitoring, control and diagnostics, remote repairs, preventive and predictive maintenance. The different level and wide range of smart services provides valuable insights into smart services in SMEs in different contexts. It was the aim to select companies from the same industry, but in different maturity phases in their service transformation journey. The details of the case companies are described in Table 2.

Table 2: Case company description

\begin{tabular}{llll}
\hline Firm & Respondent & Number of employees & The length of smart service provision in years \\
\hline A & Owner & 15 & 1 \\
B & Product manager & 50 & 1 \\
C & Owner & 10 & 2 \\
D & Owner & 4 & 2 \\
E & Owner & 25 & 2 \\
F & Owner & 148 & 2 \\
G & Product Manager & 170 & More than 2 \\
\hline
\end{tabular}

Source: Author compilation

The qualitative research consists of in-depth interviews with owners or with experienced senior managers in the selected organizations. The interviews were carried out from April 2017 to January 2018. Each interview lasted from 50 to 100 minutes and was performed on site, which gave a chance to tour each company and get a sense of the work environment. All interviews were recorded and transcribed. After selecting the case companies, semi-structured interviews with predefined themes were conducted.

The interview consisted of open-ended questions, which were based on the literature review. All interviews were done face-to-face. Open coding was used to organize the data and convert them to discrete thematic blocks. As qualitative case research is sensitive to researchers' subjective interpretations, some checks and peer debriefing to reduce researcher bias were conducted to increase the objectivity of the study.

\section{Results}

The respondents were asked which assumptions were crucial for their smart service provision. All respondents $(100 \%)$ agreed on the importance of positive perception of smart service provision by top management or owners. It would not be possible to start with smart services without their positive perception. Also, enthusiasm and desire to start are very important at the beginning of smart service provision. All respondents agreed on the necessity of these two assumptions.

The categories of drivers behind beginning with smart service provision were distributed to the main five areas, such as: competitive advantage, current trends, data, finance and product. The main driver is to gain competitive advantage according to the respondents. Usually a combination of more drivers led to smart service provision (Kanovska \& Tomaskova, 2018a).

Based on the findings, remote monitoring, remote diagnostics and remote control and repairs, are naturally offered by the majority of respondents. Predictive maintenance and product innovation are now provided infrequently. However, these areas will definitely gain significance, and become not only a competitive practice, but a commonplace one (Kanovska \& Tomaskova, 2018b). 
Initiation to start with smart service provision was on the side of the electrotechnical company (71\% respondents), on the side of customers (14\% respondents) and on the side of competition (14\% respondents).

The aim of this paper is to investigate which benefits of smart services are the most significant for manufacturing companies. Therefore, the analysis of the section related to possible benefits of smart service provision identified two research questions (RQ), which were formulated in two following statements RQ1 and RQ2.

RQ1: Which benefits have you realized for your own business by providing smart services? RQ2: Which benefits have you realized for your customers by providing smart services?

\subsection{Benefits of smart services for SMEs}

The benefits of smart service provision have been realized by respondents are the following ones:

- Differentiate from competition (4x)

- Provide faster, cheaper or easier product maintenance and repairs $(3 \mathrm{x})$

- Gather valuable information (e.g. for service development) $(2 x)$

- Increase reliability of products $(2 \mathrm{x})$

- Realize higher prices $(1 \mathrm{x})$

The numbers in the brackets shows the number of respondents who mentioned the particular benefit. The Figure 1 shows the most important benefits of smart service provisions for the respondents of the research in small and medium electrotechnical companies.

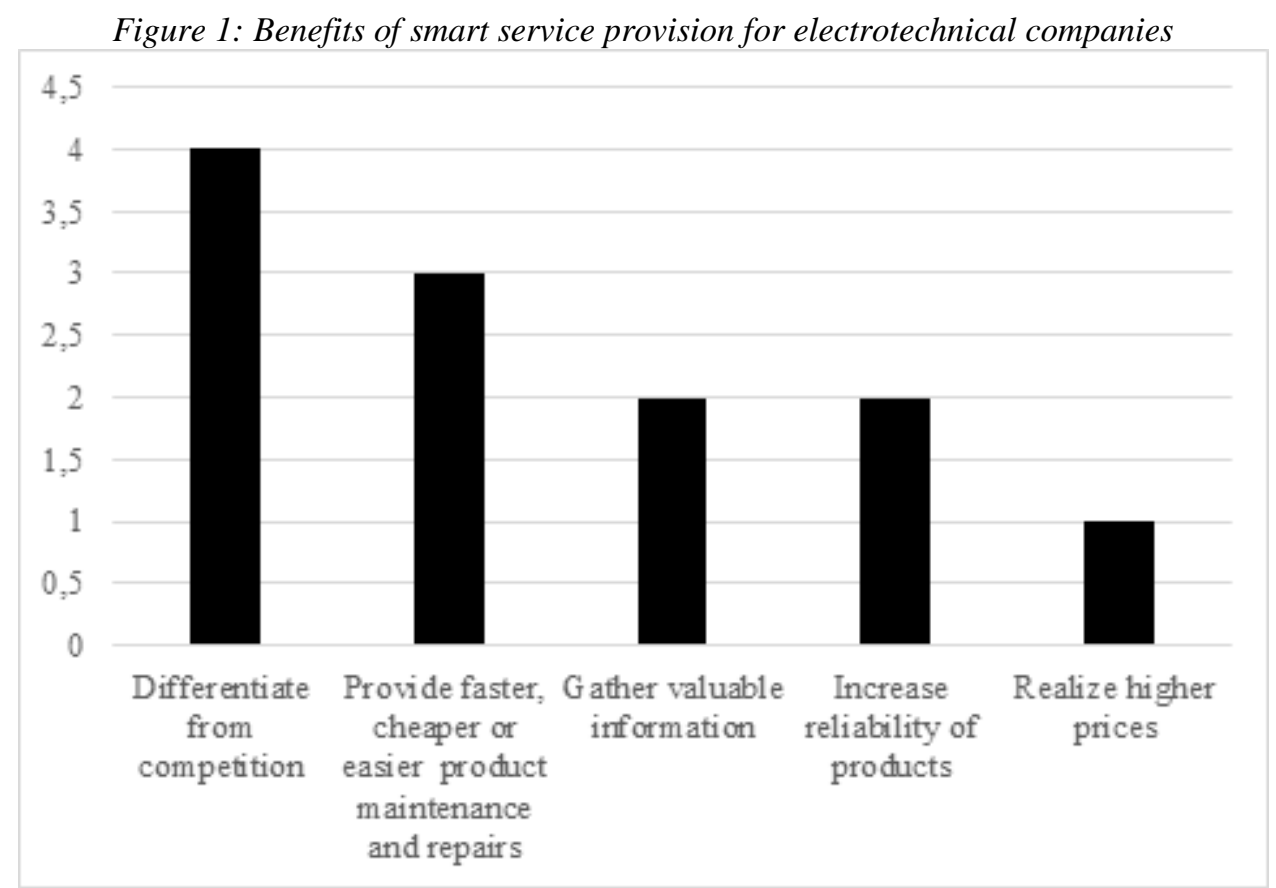

Source: Author compilation

Financial benefit of smart service provision is perceived by $43 \%$ of respondents. On the other hand, $14 \%$ of them do not perceive financial benefits in smart services and $29 \%$ of respondents are not sure or they do not know exactly. The respondents do not usually record the benefits of smart service provision. However, they will definitely plan to track this area over time. There is currently no publicly available empirical study about smart service provision in electrotechnical companies in the Czech Republic. Even if different companies implement the 
same DSST, the benefit will be different for each company and will be measured in other parameters depending on its usage and current situation. The benefits of smart services can therefore only be measured and demonstrated in a particular company by monitoring the development of the parameters that a company wants to improve by implementing smart services.

The future of smart services is perceived by all respondents very positively and they become a necessity for industrial enterprises.

\subsection{Benefits of smart services for customers of SMEs}

The benefits for customers by proving smart services have been realized by seven respondents are the following ones:

- Increase reliability and safety of products $(3 x)$

- Get faster product maintenance and repairs (e.g. remotely connected) (3x)

- Reduce costs (e.g. for transport, repairs) $(3 \mathrm{x})$

- Gather valuable information (e.g. 24/7 control of product operations, new functions of products) (2x)

- Get comfort solution (1x)

The numbers in the brackets shows the number of respondents who mentioned the particular benefit. The Figure 2 presents the most important benefits of smart service provisions for customers of the respondents in electrotechnical SMEs.

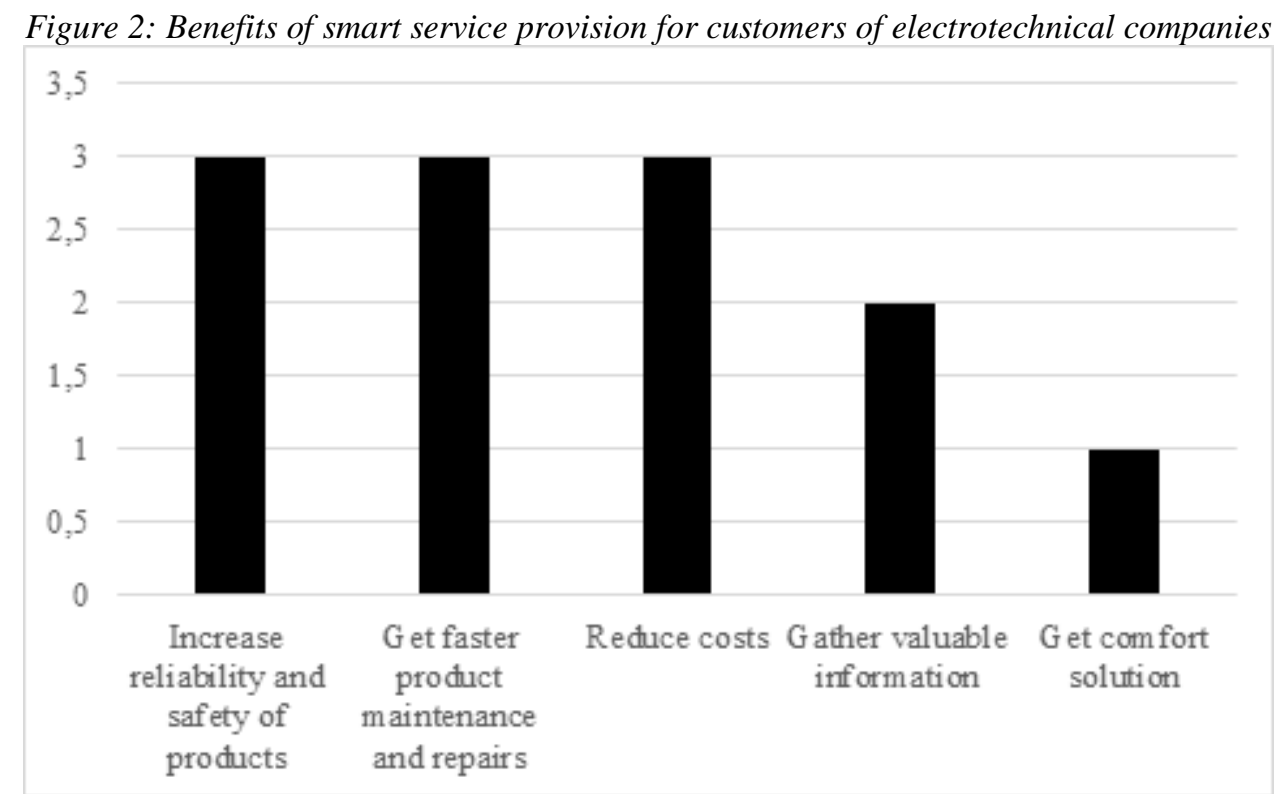

Source: Author compilation

\section{Discussion}

The focus of this paper has been an investigation of benefits connected to smart service provision for manufacturers and for their customers. The qualitative research was held in seven electrotechnical companies in the Czech Republic, South Moravian Region. Two research questions were formulated in this paper to discover which benefits are the most important for manufacturers from SMEs and for their customers. 


\subsection{Theoretical Implications}

The research reveals the benefits from smart service provision in SMEs. The most mentioned benefits by manufacturers for their company are differentiation from competition and provision of faster, cheaper or easier product maintenance / repairs. The most mentioned benefits by manufacturers for their customers are increasing of reliability and safety of products, faster product maintenance / repairs and reducing costs.

To sum up, the most important benefits according to respondents from seven case companies are in relation to Table 1 mentioned above and from four main following areas:

- differentiation from competition,

- product maintenance / repairs,

- reliability and safety of products,

- reducing costs.

The majority of research focuses on the general benefits of smart service provision for service providers or the impact, both positive and negative, from the view of the customer (Grubic et al., 2011; Grubic, 2014). For instance, Wünderlich et al. (2015) focus on perceived embeddedness of end customers and their concerns regarding risk, concluding that companies need to adapt their business models as well as organization due to changed behaviors of consumers (Wünderlich et al., 2015; Benedettini et al., 2015).

In the context of global area, it is the biggest potential of remote monitoring technology rests in preventing machinery breakdown, hence using the technology in proactive way (Grubic, 2014). The potential to act proactively in stopping or preventing breakdowns, means manufacturers are able to deliver more attractive value propositions to their customers. The transfer of risks and reduction of surprises that accompany this are such value propositions. The major risks here are non-availability of the product and its suboptimal performance.

Allmendinger \& Lombreglia (2005) state that services enabled by remote monitoring technology create very appealing value for customers, i.e. value of removing unpleasant surprise from their business. Similar is observed by Brax \& Jonsson (2009) who concluded that customers emphasize risk reduction and transfer of risks to the manufacturer, mainly in the form of technological and operational risks, rather than cost savings. Moreover, Lim et al. (2018) confirm that the use of sensor data gained from electronics is a very suitable method for better understanding individual customer processes that complements existing methods.

\subsection{Managerial Implications}

Nevertheless, all case companies from the qualitative research agreed that smart services are the future of manufacturing. In some industries, smart services are still perceived as a possible competitive advantage, but in a couple of years, smart services will be a necessity. It is likely that sustainable competitive advantage may be achieved through complex combinations of interconnected products and services found within manufacturers, customers and intermediaries, if needed. One of the findings from the study conducted by Grubic et al. (2011) reveals that more than half of companies they surveyed characterizes capability enabled by remote monitoring technology as very relevant for their future success and competitiveness.

The literature revealed the following three benefits: cost reduction, insight into customers' needs and feedback for R\&D that enables learning and knowledge creation (Grubic, 2014). Some non-monetary benefits are seen in the opportunity to learn more from customers and their product using, establishing a basis for research and development, sales or marketing activities (Laine et al., 2010). 
It is still not too clear how remote monitoring technology can be used to gain insight into customers' needs and how this data can be used in R\&D and what factors are essential for this. As Lim et al. (2018) add the variety and amount of data that can be gathered from individuals will continue to rise. However, in the context of global area, if the problem could not be solved, a service technician was dispatched to the customer's site. When the first products with internet connection became available, the company's service quickly realized the benefits that could be gained from them (Klein, 2017). Therefore, manufacturers should use all possible benefits of smart service provision and focus on better promotion of these services to their customers and do better publicity in general (e.g. conferences, workshops, newspapers, magazines, face-toface meetings).

\section{Conclusion}

Manufacturing is still developing and taking place in different forms. During last years, manufacturing companies were attracted by the concept of internet of things. The term describing the production of tomorrow is smart manufacturing. Smart manufacturing integrates manufacturing assets of today, and tomorrow with sensors, computing platforms, communication technology, data intensive modelling, control, simulation and predictive engineering (Kusiak, 2018; Wunderlich, 2015). Security, competitiveness and strategic view are core priorities of manufacturing companies with smart service offering in the period of globalization.

The paper was focused on the benefits of smart services, which are the most important for SMEs. By reflecting on the findings of the research in seven electrotechnical SMEs, respondents identified four broad areas that are connected to benefits. The areas are the following ones: differentiation from competition, product maintenance / repairs, reliability and safety of products, reducing costs. In respect to the findings from the research and also examples found in the literature clearly point to the fact that manufacturers are still struggling to articulate benefits from smart services that would be appealing to them and to customers.

More research is necessary to understand and address this problem. Therefore, future studies should investigate further how to process the benefits of smart services. The next research could be extended to other companies, which also provide smart services to their customers, from different industries.

\section{References}

Allmendinger, G. \& Lombreglia, R. (2005). Four Strategies for the Age of Smart Services. Harvard Business Review, 83(10), 131-145.

Baines, T. et al. (2017). Servitization: Revisiting the State-of-the-Art and Research Priorities. International Journal of Operations \& Production Management, 37(2), 256-278.

Benedettini, O., Neely, A. \& Swink, M. (2015). Why Do Servitized Firms Fail? A Risk-Based Explanation. International Journal of Operations and Production Management, 35(6), pp. 946-979.

Beverungen, D., Matzner, M. \& Janiesch, C. (2017). Information Systems for Smart Services. Information Systems and e-Business Management, 15(4), 781-787.

Brax, S. \& Jonsson, K. (2009). Developing Integrated Solution Offerings for Remote Diagnostics: A Comparative Case Study of Two Manufacturers. International Journal of Operations \& Production Management, 29(5), 539-560.

Christensen, C. (1997). The Innovators Dilemma. New York. USA: HarperCollins.

Cusumano, M.A., Kahl, S.J. \& Suarez, F.F. (2015). Services, Industry Evolution, and the Competitive Strategies of Product Firms. Strategic Management Journal, 36(4), 559-575.

Davies, A., Brady, T. \& Hobday, M. (2007). Organizing for Solutions: Systems Seller vs. Systems Integrator. Industrial Marketing Management, 36(2), 183-193. 
Gebauer, H., Gustafsson, A. \& Witell, L. (2011). Competitive Advantage Through Service Differentiation by Manufacturing Companies. Journal of Business Research, 64(12), 1270-1280.

Greenstein, S. (2010). Digitalization and Value Creation. IEEE Micro, 30(4), 4-5.

Gremyr, I., Löfberg, N. \& Witell, L. (2010). Service Innovations in Manufacturing Firms. Managing Service Quality, 20(2), 161-175.

Grubic, T. (2014). Servitization and Remote Monitoring Technology. Journal of Manufacturing Technology Management, 25(1), 100-124.

Grubic, T. \& Peppard, J. (2016). Servitized Manufacturing Firms Competing Through Remote Monitoring Technology. Journal of Manufacturing Technology Management, 27(2), 154-184.

Grubic, T., Redding, L., Baines, T. \& Julien, D. (2011). The Adoption and Use of Diagnostic and Prognostic Technology Within UK-Based Manufacturers. Proceedings of the Institution of Mechanical Engineers, Part B: Journal of Engineering Manufacture, 225(8), 1457-1470.

Grubic, T. \& Jennions, I. (2017). Remote Monitoring Technology and Servitised Strategies-Factors Characterising the Organisational Application. International Journal of Production Research, 56(6), 1-17.

Jonsson, K. \& Holmström, J. (2005). Ubiquitious Computing and the Double Immutability of Remote Diagnostics Technology: An Exploration into Six Cases of Remote Diagnostics Technology Use. Designing Ubiquitous Information Environments: Socio-Technical Issues and Challenges, Springer, 153-167.

Jonsson, K., Westergren, U. H. \& Holmström, J. (2008). Technologies for Value Creation: An Exploration of Remote Diagnostics Systems in the Manufacturing Industry. Information Systems Journal, 18(3), $227-245$.

Kamp, B., Ochoa, A. \& Diaz, J. (2017). Smart Servitization Within the Context of Industrial User-Supplier Relationships: Contingencies According to a Machine Tool Manufacturer. International Journal on Interactive Design and Manufacturing, 11(3), 651-663.

Kanovska, L. \& Tomaskova, E. (2018a) Drivers for Smart Servitization in Manufacturing Companies. AGRIS online Papers in Economics and Informatics, 10(3), 57-68.

Kanovska, L. \& Tomaskova, E. (2018b). Data Gained from Smart Services in SMEs-Pilot Study. Proceedings of the Computational Methods in Systems and Software, Springer, 183-200.

Klein, M.M. (2017). Design Rules for Smart Services: Overcoming Barriers with Rational Heuristics (Doctoral dissertation, Universität St. Gallen).

Kowalkowski, C., Windahl, C., Kindström, D. \& Gebauer, H. (2015). What Service Transition? Rethinking Established Assumptions about Manufacturers' Service-Led Growth Strategies. Industrial Marketing Management, 44(2), 59-69.

Kowalkowski, C., Gebauer, H. \& Oliva, R. (2017). Service Growth in Product Firms: Past, Present, and Future. Industrial Marketing Management, 60, 82-88.

Kusiak, A. (2018). Smart Manufacturing. International Journal of Production Research, 56(1-2), 508-517.

Kussel, R., Liestmann, V., Spiess, M. \& Stich, V. (2000). "TeleService" a Customer-Oriented and Efficient Service? Journal of Materials Processing Technology, 107(1-3), 363-371.

Laine, T., Paranko, J. \& Suomala, P. (2010). Downstream Shift at a Machinery Manufacturer: The Case of the Remote Technologies. Management Research Review, 33(10), 980-993.

Lee, J., Kao, H-A. \& Yang, S. (2014). Service Innovation and Smart Analytics for Industry 4.0 and Big Data Environment. Procedia Cirp, 16, 3-8.

Lepak, D.P., Smith, K.G. \& Taylor, M.S. (2007). Value Creation and Value Capture: A Multilevel perspective. Academy of Management Review, 32(1), 180-194.

Lim, C., Kim, M.J., Kim, K.H., Kim, K.J. \& Maglio, P.P. (2018). Using Data to Advance Service: Managerial Issues and Theoretical Implications from Action Research. Journal of Service Theory and Practice, 28(1), 99128.

Mathieu, V. (2001). Product Services: From a Service Supporting the Product to a Service Supporting the Client. Journal of Business \& Industrial Marketing, 16(1), 39-61.

Matthyssens, P. \& Vandenbempt, K. (2008). Moving from Basic Offerings to Value-Added Solutions: Strategies, Barriers and Alignment. Industrial Marketing Management, 37(3), 316-328.

Neu, W.A. \& Brown, S.W. (2005). Forming Successful Business-To-Business Services in Goods-Dominant Firms. Journal of Service Research, 8(1), 3-17.

Oliva, R. \& Kallenberg, R. (2003). Managing the Transition from Products to Services. International Journal of Service Industry Management, 14(2), 160-172.

Ostrom, A.L, Parasuraman, A., Bowen, D.E., Patricio, L. \& Voss, C. A. (2015). Service Research Priorities in a Rapidly Changing Context. Journal of Service Research, 18(2), 127-159.

Porter, M.E. \& Heppelmann, J.E. (2014). How Smart, Connected Products Are Transforming Competition. Harvard Business Review, 11, 1-23. 
Rifkin, J. (2014). The zero Marginal Cost Society: The Internet of Things, The Collaborative Commons, and the Eclipse of Capitalism. London, UK: Macmillan.

Schroeder, A. \& Kotlarsky, J. (2015). Digital Resources and Their Role in Advanced Service Provision: A VRIN Analysis. Proceedings of the Spring Servitization Conference 2015. Paper presented at SSC2015 conference. UK: Birmingham.

Vandermerwe, S. \& Rada, J. (1988). Servitization of Business: Adding Value by Adding Services. European Management Journal, 6(4), 314-324.

Vargo, S.L. \& Lusch, R.F. (2008). Service-Dominant Logic: Continuing The Evolution. Journal of the Academy of marketing Science, 36(1), 1-10.

Vendrell-Herrero, F. \& Wilson, J. R. (2016). Servitization for Territorial Competitiveness: Taxonomy and Research Agenda. Competitiveness Review, 26(5), 2-11.

Visnjic, I. \& Van Looy, B. (2013). Servitization: Disentangling the Impact of Service Business Model Innovation on Manufacturing Firm Performance. Journal of Operations Management, 31(4), 169-180.

Westergren, U.H. (2011). Opening up Innovation: The Impact of Contextual Factors on the Co-Creation of ITEnabled Value Adding Services within the Manufacturing Industry. Information Systems and E-Business Management, 9(2), 223-245.

Wise, R. \& Baumgartner, P. (2000). Go Downstream: The New Profit Imperative in Manufacturing. IEEE Engineering Management Review, 28(1), 89-96.

Wunderlich, N.V. et al. (2015). Futurizing Smart Service: Implications for Service Researchers and Managers. Journal of Services Marketing, 26(1), 442-447. 